\title{
Distribution of the isopod Excirolana braziliensis on sandy beaches of the Atlantic and Pacific Oceans
}

\author{
Gastón Martínez $^{1,2, *}$, Matías Arim ${ }^{1,2}$, Omar Defeo ${ }^{1,2}$
}

\begin{abstract}
${ }^{1}$ Centro Universitario de la Región Este (CURE), Universidad de la República, Ruta 9 y Ruta 15, PC 27000 Rocha, Uruguay ${ }^{2}$ Departamento de Ecología y Evolución, Facultad de Ciencias, Universidad de la República, PC 11400 Montevideo, Uruguay
\end{abstract}

\begin{abstract}
We assessed geographic patterns of abundance of the isopod Excirolana braziliensis across its whole distribution range in the context of the abundant centre hypothesis (ACH). We also evaluated auxiliary hypotheses to the $\mathrm{ACH}$ involving habitat availability and suitability. We compiled species abundance and occurrence information on 139 Pacific and Atlantic sandy beaches of the Americas. Abundance patterns were contrasted against 5 hypothetical distribution models. Habitat availability (sandy beach along the coast), and the role played by grain size on isopod abundance were analysed. Maximum entropy niche modelling based on primary production, salinity, water temperature and tidal range data was used to estimate trends in habitat suitability. E. braziliensis abundance peaked at the 2 edges of its range on the Atlantic coast and towards the centre of its range on the Pacific coast. Congruently, the niche model predicted very low habitat suitability at the centre of the species' range on the Atlantic coast. Primary production was the main contribution to the model $(74.8 \%)$. The highest abundances were found in fine sediments $(0.20 \mathrm{~mm})$. Support for the ACH for E. braziliensis was found only for the Pacific coast, whereas habitat suitability and availability together with local in-beach morphodynamics accounted for deviations from $\mathrm{ACH}$ predictions in the Atlantic. The highest abundances registered in upwelling areas and on beaches with fine sands highlight the primary role played by regional and local conditions over geographic location.
\end{abstract}

KEY WORDS: Abundant-centre hypothesis $\cdot$ Habitat availability $\cdot$ Primary production $\cdot$ Salinity · Sandy beaches $\cdot$ Surface water temperature

\section{INTRODUCTION}

The abundant centre hypothesis $(\mathrm{ACH})$ provides a mechanistic explanation for geographic trends in species abundance (Brown 1984). The ACH states that species abundance is highest in the centre of the range and decreases towards the limits in response to spatial trends in physiological (e.g. thermal) and ecological (e.g. biological interactions) performance (Brown 1984, Sagarin \& Gaines 2002b). However, species exhibit variable distribution patterns across their geographic ranges (Sagarin \& Gaines 2002a). Among 34 species studied in coastal ecosystems, only 8 showed normal or inverse quadratic models of abundance as predicted by the $\mathrm{ACH}$ (Sagarin \& Gaines 2002b, Samis \& Eckert 2007, Tuya et al. 2008,

*Corresponding author: gmartinez@cure.edu.uy
Rivadeneira et al. 2010, Fenberg \& Rivadeneira 2011, Tam \& Scrosati 2011, Baldanzi et al. 2013). This contradictory support for the $\mathrm{ACH}$ might reflect the occurrence of optimal conditions for peak abundance near species limits (ramped models, 13 species). However, for some species (13), no patterns were found, although some patterns may have been masked by a peak and tail pattern (McGill \& Collins 2003). The failure of auxiliary hypotheses related to habitat availability (Samis \& Eckert 2007) or life history traits (Rivadeneira et al. 2010) could also explain deviations from the predictions of the ACH (Brown 1984, Martínez-Meyer et al. 2013). Indeed, discontinuous distributions associated with environmental conditions and species interactions have been reported elsewhere (Sagarin et al. 2006).

(C) The authors 2017. Open Access under Creative Commons by Attribution Licence. Use, distribution and reproduction are unrestricted. Authors and original publication must be credited. 
Sandy beaches present an ideal system for assessing geographical patterns in abundance because they are essentially 1 -dimensional (i.e. $<0.1 \mathrm{~km}$ wide at all points) (Sagarin et al. 2006). The morphodynamic environment of benthic macrofauna is characterized by interactions among tidal regimes, wave conditions and sediment types (Defeo \& McLachlan 2005), which typically account for the spatial variation in abundance of sandy beach species at different scales (Baldanzi et al. 2013). However, identification of large-scale distribution patterns is often limited by the restricted spatial coverage of most studies, partial samplings and use of different methods (Defeo \& McLachlan 2005).

The cirolanid isopod Excirolana braziliensis is an excellent candidate for addressing biogeographic distribution patterns. In America, there are 8 species of the genus Excirolana that range from Canada to Chile in the Pacific and from the USA to Argentina in the Atlantic. Among them, E. braziliensis has the widest distribution on both sides of tropical and subtropical America, inhabiting micro- and macro-tidal beaches with fine and coarse sands from the Gulf of California to southern Chile in the Pacific and from the Gulf of Mexico to Uruguay in the Atlantic. Populations are largely isolated because the species' ovoviviparous mode of development limits its dispersal (Weinberg \& Starczak 1988). In addition, E. braziliensis has been sampled with similar methodologies in several studies over most of its distribution in the 2 oceans.

Sandy beach ecosystems are facing escalating anthropogenic pressures, and this isopod has been used as bioindicator regarding ecosystem health (Betz et al. 1982, Veloso et al. 2011, Vieira et al. 2012), and also to assess the role played by natural impacts (e.g. tsunamis; Jaramillo et al. 2012). Lastly, E. braziliensis plays an important role in sandy beach food webs as a primary consumer (Lercari et al. 2010).

We investigated variation in E. braziliensis abundance across its geographic range on Atlantic and Pacific sandy beaches of the Americas, encompassing 4 and 3 biogeographic provinces, respectively. Our goals were to assess latitudinal patterns in abundance and to evaluate the roles of habitat suitability, habitat availability and beach morphodynamics in shaping the species' occurrence and abundance.

\section{MATERIALS AND METHODS}

The methodological approach can be summarized as follows: we first analysed abundance data of
Excirolana braziliensis and tested the $\mathrm{ACH}$. Then, a predictive species distribution model (PSDM) was developed for each ocean, considering the role of habitat suitability on distribution patterns. The PSDM took into account the roles of primary production, tidal range, salinity and water temperature as predictors of isopod distribution. The role played by habitat availability in geographic trends of abundance was analysed by assessing the proportion of sandy beach habitat throughout the geographic range of the species. Finally, we analysed the role played by grain size, a widely used proxy for beach morphodynamics (Defeo \& McLachlan 2005).

\section{Species}

Cirolanid isopods are conspicuous members of sandy beaches around the world and are dominant in terms of numbers or biomass (Soares 2003). Excirolana braziliensis is a dioecious species: embryos recruit to the adult population as juveniles or 'mancas' (Martínez \& Defeo 2006). It is an active swimmer and shows burrowing optima in a wide range of grain sizes (Yannicelli et al. 2002).

\section{Data}

Our database included information on the occurrence and abundance of $E$. braziliensis and grain sizes from Atlantic $(n=105)$ and Pacific $(n=77)$ sandy beaches. Using Scopus, JSTOR and Google Scholar search engines, we compiled information on species abundance and occurrence along with environmental variables. Unpublished data from Uruguayan sandy beaches were also integrated into the database. The data covered the period from 1972 to date (see Table S2 in the Supplement at www.int-res.com/articles/suppl/m583p137_supp.pdf). We approximated abundance data from graphics (Nava \& Severyn 2010) only in 2 cases. When monthly or seasonal surveys were present in the data sources, the species pool collected across all samples reported was used to provide only 1 estimate for each beach.

\section{Testing the ACH}

We analysed the geographic patterns of abundance of $E$. braziliensis separately for Atlantic (n = $77)$ and Pacific $(n=62)$ beaches. Large-scale varia- 
tions in abundance were assessed in terms of density (ind. $\mathrm{m}^{-2}$ ) because most data in the literature were expressed in this unit. When more than one estimate was available for the same beach, a mean value was computed. Relative densities (RDs) were estimated by dividing the densities by the maximum value observed in the geographic range. Geographical positions were standardised by the expression $\mathrm{RI}=2 \times(L-S) \times R^{-1}$, where $\mathrm{RI}$ is the range index, $L$ is the latitude, $S$ is the latitudinal midpoint, and $R$ is the total range of the species (Sagarin \& Gaines 2002a). RI ranges from -1 to 1 , with values close to zero indicating that the site is located near the centre of the range and values close to -1 and 1 indicating that the site is near the southern and northern range limits, respectively.

The distribution of abundance along the species' geographic range was contrasted with 5 biogeographical models that encompass theoretical expectations and previously reported patterns (Sagarin \& Gaines 2002b, Fenberg \& Rivadeneira 2011). These models were (1) a normal distribution; (2) an inverse quadratic distribution, which assumes that the maximum abundance is reached symmetrically at the centre of the distribution and that abundance decline gradually towards the edges; (3) the abundant edge distribution, which predicts maximum abundances at the 2 edges of the range and minimum densities at the centre; and ( 4 \& 5) ramped northern and southern distributions, which assume that abundance declines from one range limit to the other, with intermediate abundance at the centre of the range. We also considered (6) a null model of constant abundance across the geographical distribution of the species.

The goodness of fit of each model to the observed data was evaluated by calculating the residual sum of squared deviations (RSS) for sites exceeding the constraint boundary generated by each model (Sagarin \& Gaines 2002b). Small values of RSS indicate a good fit between the model and the observed data. The significance of the observed RSS values was evaluated by generating 1000 randomized values of RI and relative abundance. The fit of the model was considered significant when the observed RSS value was lower than the $5^{\text {th }}$ percentile of the randomised distribution. The degree of support for each model was evaluated by calculating Akaike's information criterion (AIC), and all models with Akaike weights $\left(\mathrm{AIC}_{\mathrm{w}}\right)>0.25$ were selected. Analyses were carried out using a script in R v.2.11 (R Development Core Team 2007) written by Fenberg \& Rivadeneira (2011).

\section{Predictive species distribution modelling}

A PSDM was built using Maxent v.3.4.1 software (Phillips et al. 2017; https://biodiversityinformatics. amnh.org/open_source/maxent/). The environmental layers used for modelling were mean annual estimates of primary production $\left(\mathrm{mg} \mathrm{C} \mathrm{m}^{-2} \mathrm{~d}^{-1}\right)$, salinity, sea surface temperature $\left({ }^{\circ} \mathrm{C}\right)$, its $\mathrm{SD}$ and tidal range. All variables were obtained from the AquaMaps environmental dataset with a $0.5^{\circ}$ grid cell resolution (Kaschner et al. 2008), except for tidal range, which was obtained from OSU Tidal Data Inversion with a $0.25^{\circ}$ grid cell resolution (Egbert \& Erofeeva 2002). The AquaMaps dataset was also used to analyse other invertebrate coastal species' distributions, including sandy beach ecosystems (Hermosilla et al. 2011, Lee \& Riberos 2011, Barboza \& Defeo 2015). The distribution model was built using presence data of $E$. braziliensis along its geographical distribution and 10005 background points, using $50 \%$ of the localities for training, and the remaining $50 \%$ for model testing. Presence records from beaches $<0.5^{\circ}$ distant in latitude or longitude were considered redundant and removed from the analysis. The final screening reduced our dataset from 182 to 70 sandy beach locations; 36 from the Pacific Ocean and 34 from the Atlantic Ocean. The $10^{\text {th }}$ percentile training presence logistic threshold was used, which provided the minimum requirements for the species' climate preferences. The output format is Cloglog, and model performance was measured by the average area under the curve $(\mathrm{AUC}) \pm \mathrm{SD}$; AUC ranges between 0 and 1 (maximum) (Phillips et al. 2017). Spatial autocorrelation was examined considering all environmental variables for each sampling point based on Moran's I index and using the distance criterion included in the Spatial Analysis in Macroecology v.1.1 (SAM) software (Rangel et al. 2006). The percentage contribution of each variable to the final model was retained. Auxiliary estimates of the contributions of each variable to the final model were provided by jackknife tests (Phillips et al. 2006).

\section{Habitat availability}

We measured the amount of sandy beach habitat present throughout (and beyond) the geographic range of E. braziliensis using Google Earth v.6.0.3.2197, following Fenberg \& Rivadeneira (2011). We traced the contours of the Atlantic coast from $42^{\circ} 00^{\prime} \mathrm{S}$ (Peninsula Valdez, Argentina) to $36^{\circ} 27^{\prime} \mathrm{N}$ (North Carolina, USA) and the Pacific coast from $48^{\circ} 37^{\prime} \mathrm{S}$ (Isla Cam- 
pana, Chile) to $34^{\circ} 46^{\prime} \mathrm{N}$ (California, USA) in cumulative, $400 \mathrm{~km}$ sections at a constant elevation of $500 \mathrm{~m}$. Within each section, we measured the amount of coastline that consisted of sandy beach habitat by summing each stretch and calculating the percentage of suitable habitat per section. Natural gaps of sandy beaches were also measured in each section as rocky shores, estuaries, mangroves/swamps/marshes/ forest patches and anthropogenic infrastructure.

\section{Grain size}

Data on sand grain size for each beach was obtained (see references in Table S2) and standardised to $\mathrm{mm}$. We estimated the frequency of occurrence for each grain size class as defined by Wentworth (1922) as follows: very fine $(0.063-0.125 \mathrm{~mm})$, fine $(0.125-$ $0.250 \mathrm{~mm})$, medium $(0.250-0.500 \mathrm{~mm})$ and coarse (0.500-1 mm). We also analysed geographic variation in grain size across the distributional range of $E$. braziliensis. To analyse the abundance-grain size relationship for each ocean, we modelled the upper boundaries of abundance for each grain size class, determining a constraint envelope pattern (CEP; sensu Caddy \& Defeo 2003). This procedure involves dividing grain size into intervals of equal length $(0.1 \mathrm{~mm})$ and recording the maximum value of the response variable (abundance) for each interval. Then, the relationship defined by the points of the upper boundary is visualised through a simple scatter plot, and the appropriate model is fitted. The upper limit corresponds to optimal combinations of grain size and abundance, whereas values within this 'envelope' represent a wide range of suboptimal conditions.

\section{RESULTS}

In the Atlantic Ocean, Excirolana braziliensis showed an asymmetric geographic distribution covering $56^{\circ}$ in latitude (Fig. 1). The northernmost site was Progreso (Yucatan, Mexico: $21^{\circ} 16^{\prime} \mathrm{N}, 89^{\circ} 49^{\prime} \mathrm{W}$ ), the southernmost site was Manantiales (Maldonado, Uruguay: $34^{\circ} 50^{\prime} \mathrm{S}, 54^{\circ} 50^{\prime} \mathrm{W}$ ), and the centre of the range was at Lucena, Paraíba, Brazil (6 $6^{\circ} 2^{\prime} \mathrm{S}$, $34^{\circ} 54^{\prime} \mathrm{W}$ ) (Fig. 1). In the Pacific Ocean, there was also an asymmetric distribution covering ca. $73^{\circ}$ in latitude and 3 biogeographic provinces (Fig. 1). The northernmost site was Puerto Peñasco, México $\left(31^{\circ} 18^{\prime} \mathrm{N}, 113^{\circ} 37^{\prime} \mathrm{W}\right)$ in the Gulf of California, and the southernmost site was at Chiloe Island, Chile $\left(41^{\circ} 53^{\prime} \mathrm{S}, 74^{\circ} 00^{\prime} \mathrm{W}\right)$. The centre of the range was at Tortuga Beach, Piura, Peru $\left(5^{\circ} 16^{\prime} \mathrm{S}, 81^{\circ} 18^{\prime} \mathrm{W}\right)$ (Fig. 1).

\section{Geographic patterns of abundance and distribution models}

Abundance patterns in the Atlantic Ocean followed the abundance edge model, which showed the lowest RSS value and the best fit, denoted by an $\mathrm{AIC}_{\mathrm{w}}$ value close to 1 (see Table S1 in the Supplement at www.int-res.com/articles/suppl/m583p137_ supp.pdf). The highest abundance in the Southern Atlantic was registered at Praia do Pontal Beach in Rio de Janeiro (Brazil) (350 ind. $\mathrm{m}^{-2}$ ) and in the northern Atlantic, at La Mancha Beach in Veracruz (Mexico) (210 ind. $\mathrm{m}^{-2}$ ) (Fig. 1). Towards the centre of the range, the lowest abundance occurred at Ilhéus Beach, Bahía, Brazil (34 ind. $\mathrm{m}^{-2}$; Fig. 1) and Castilletes, Zulia, Venezuela $\left(11^{\circ} 48^{\prime} \mathrm{N}, 71^{\circ} 30^{\prime} \mathrm{W}\right)$ (11 ind. $\mathrm{m}^{-2}$ ). From $1^{\circ} \mathrm{S}$ to $10^{\circ} \mathrm{N}$ (ca. $2800 \mathrm{~km}$ of coastline), no information on isopod occurrence was found.

The Maxent model for E. braziliensis showed an $\mathrm{AUC} \pm \mathrm{SD}$ of $0.922 \pm 0.019$. Primary production presented the largest contribution to the model $(73.4 \%)$, followed by sea surface temperature (20.7\%). Tidal range, the SD of temperature and salinity contributed $4.5,1.3$ and $0.1 \%$, respectively. The contribution of all predictors based on jackknife procedures was congruent with previous values (see Fig. S1 in the Supplement). The predicted occurrence of E. braziliensis for the Atlantic Ocean was consistent with literature reports (Fig. 1). The model predicted very low suitability in the following 3 zones: the southern limit in Uruguay and the Rio de la Plata estuary $\left(35^{\circ} \mathrm{S}\right)$; from $12^{\circ} \mathrm{S}$ up to São Luis River (ca. $2^{\circ} \mathrm{S}$, Fig. 1), which included the centre of the range, $7^{\circ} \mathrm{S}$; and from 19 to $26^{\circ} \mathrm{N}$ in the Gulf of Mexico (Fig. 1).

The inverse quadratic model best explained largescale isopod patterns in the Pacific Ocean (Fig. 2, Table S1 in the Supplement). The highest abundance was registered in Naos Island, Panama $\left(8^{\circ} 55^{\prime} \mathrm{N}\right.$, $79^{\circ} 32^{\prime} \mathrm{W}$ ), with 2147 ind. $\mathrm{m}^{-2}$, followed by Trujillo, Peru $\left(8^{\circ} 09^{\prime} \mathrm{S}, 79^{\circ} 03^{\prime} \mathrm{W}\right)$ near the centre of the range, with 1205 ind. $\mathrm{m}^{-2}$. At the edges, the highest abundances were registered in Mehuín, Chile (140 ind. $\mathrm{m}^{-2}$ ) and Bahía La Paz, Mexico (242 20' N, $110^{\circ} 20^{\prime} \mathrm{W}$ ) (238 ind. $\mathrm{m}^{-2}$; Fig. 2). Following the same trend as in Atlantic beaches, Pacific beaches showed large variation in local abundance at the same latitude, especially towards the centre of the range. 


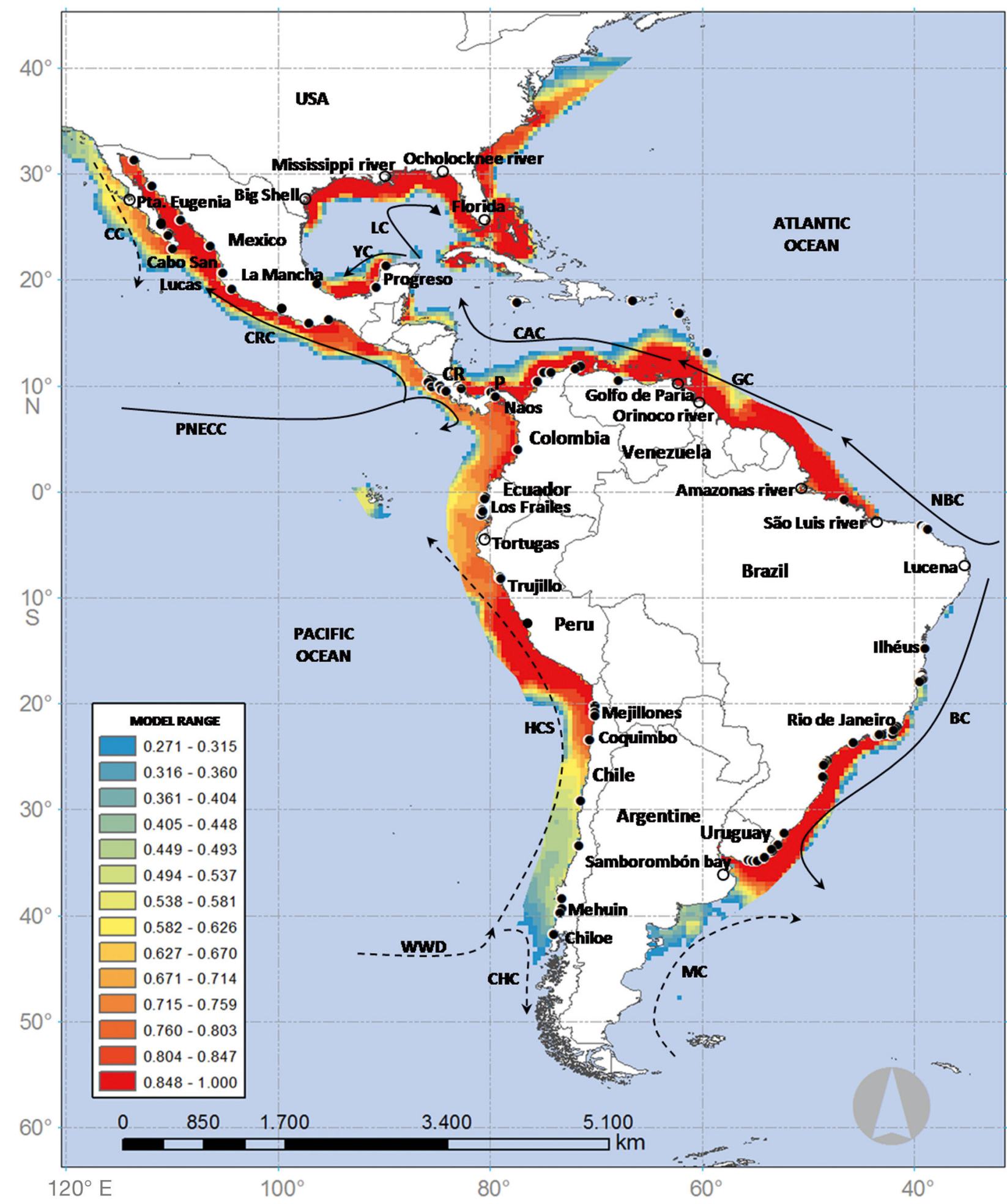

Fig. 1. Observed and predicted distribution of Excirolana braziliensis along the Atlantic and Pacific coasts of America. The colour gradient provides the predicted isopod distribution using a maximum entropy (Maxent) model. A suitability of 0.271 was used as baseline for the possible areas of distribution. Filled circles: occurrence sites; open circles: other locations mentioned in the text. CR: Costa Rica; P: Panama. Cold (dashed lines) and warm (solid lines) currents are indicated: WWD: west wind driven; CHC: Cabo de Hornos (Cape Horn); HCS: Humboldt System; ECC: Equatorial Counter; CRC: Costa Rica; CC: California; MC: Malvinas (Falklands); BC: Brazil; NBC: North Brazil; GC: Guyana; CAC: Caribbean; 


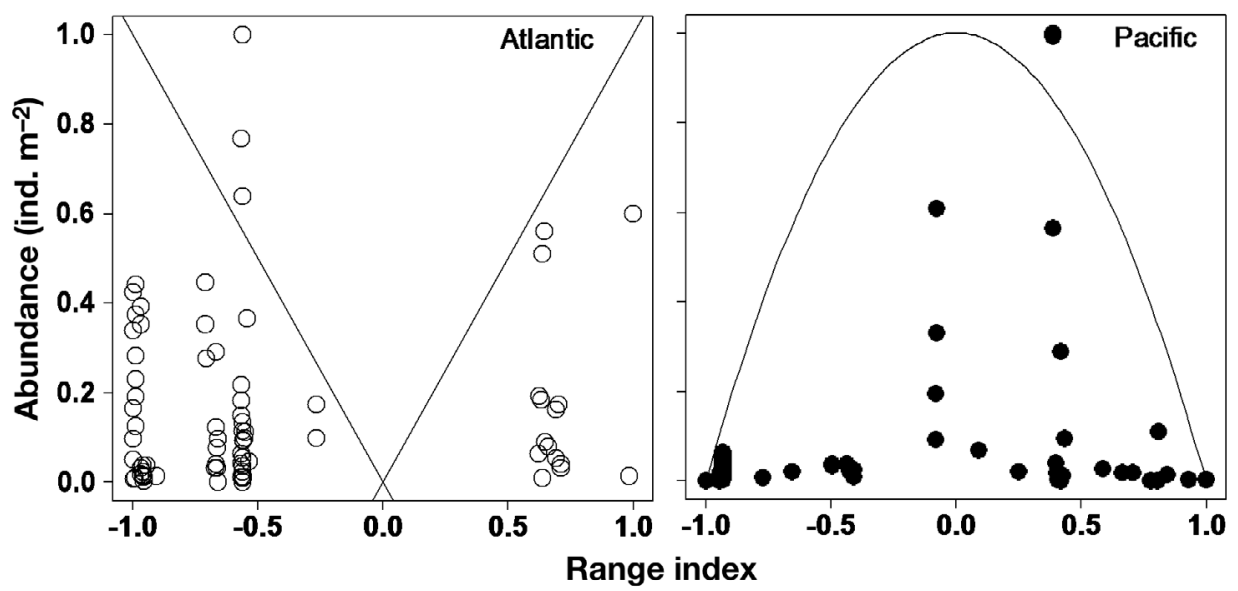

Fig. 2. Geographic variation in Excirolana braziliensis abundance. Geographic position ( $x$-axis) and abundance ( $y$-axis) are standardised. Best fit models (Akaike's information criterion weights, $\mathrm{AIC}_{\mathrm{w}}$ close to 1) are shown

The PSDM model for Pacific beaches showed a continuous distribution from $20^{\circ} \mathrm{S}$ to Punta Eugenia, Mexico $\left(27^{\circ} 51^{\prime} \mathrm{N}, 115^{\circ} 04^{\prime} \mathrm{W}\right)$ (see Fig. 1). The highest suitability values $(0.7$ and 1$)$ were predicted from Los Frailes, Ecuador ( $\left.1^{\circ} 30^{\prime} \mathrm{N}\right)$ to Topolobampo Bay in the Gulf of California, Mexico (253 $\left.34^{\prime} \mathrm{N}, 109^{\circ} 10^{\prime} \mathrm{W}\right)$. A gradual decrease was predicted southwards from $20^{\circ} \mathrm{S}$, suggesting that the southernmost limit of $E$. braziliensis in the Pacific Ocean occurs at Chiloe Island, Chile $\left(41^{\circ} 53^{\prime} \mathrm{S}, 74^{\circ} 00^{\prime} \mathrm{W}\right)$.

\section{Habitat availability}

The Atlantic coastline covers $21600 \mathrm{~km}$ and spans 4 biogeographic provinces according to Spalding et al. (2007), and it included $13900 \mathrm{~km}$ of E. braziliensis distribution. Sandy beaches represented 56\% $(12300 \mathrm{~km})$ of the coastline. Mangroves, swamps, marshes and forest patches together made up $21 \%$ of the coastline, and estuaries, rocky shores and reefs represented 12,7 and $1.6 \%$ of the coastline, respectively. Anthropogenic infrastructure represented $2 \%$ of the total. The analysis of habitat availability for $E$. braziliensis showed that marshes $(100 \mathrm{~km})$ at Samborombon Bay and the Rio de la Plata estuary constitute a physical barrier of $195 \mathrm{~km}$ (Fig. 3). In the range between 0 and $10^{\circ} \mathrm{N}$ (Amazon River to southern Venezuela) (7 bins $=2800 \mathrm{~km})$, oceanic beaches composed only $7 \%$ of the total coastline (Fig. 3). In the Gulf of Mexico, swamps and marsh stretches began to prevail north of $30^{\circ} \mathrm{N}$ (Galveston Bay, USA) along the coastline, interspersed with sandy barrier islands. Three physical barriers to isopod dispersal were apparent along the US coastline: the longshore currents convergence zone in Big Shell beach on Padre Island $\left(27^{\circ} \mathrm{N}\right.$; McGowen et al. 1977), the Mississippi and Atchafalaya River System (>200 km of coastline), and salt marshes and mangroves $(600 \mathrm{~km})$ from the Ocholocknee River mouth to Key Biscayne, Florida (Fig. 1). Northwards, sandy beaches prevailed (> 85\%) through $3200 \mathrm{~km}$ of coastline.

The Pacific coastline traced $21462 \mathrm{~km}$ along 5 biogeographic provinces and included $18017 \mathrm{~km}$ of $E$. braziliensis distribution. Sandy beaches (45\%) and rocky shores (44\%) were the most prevalent habitats. Mangroves, swamps, marshes and forest patches composed $5 \%$ of the coastline, and estuaries and anthropogenic infrastructure composed 5 and $1 \%$ of coastline, respectively. The Pacific coast consists of an interspersed mosaic of sandy beaches and rocky shores. Literature reports and the present analysis predicted that Chiloe Island (see Fig. 1) might be the species' southernmost border. Southwards, fjords with rocky intertidal habitats and estuaries became prevalent along $500 \mathrm{~km}$ (Fig. 3). From 30 to $24^{\circ} \mathrm{S}$, sandy beaches sporadically occurred (MejillonesCoquimbo, $12.3 \%$; Figs. 1 \& 3). From $24^{\circ} \mathrm{S}$ to the northern limit registered for $E$. braziliensis in the Pacific Ocean (Cabo San Lucas, Mexico; Fig. 1) and northwards to California $\left(35^{\circ} \mathrm{N}\right)$, sandy shores were well represented (Fig. 3). This result suggests that habitat availability did not play a role in determining the northernmost limit of the species' distribution in the Pacific Ocean.

\section{Relationship between $E$. braziliensis and sediment}

E. braziliensis inhabited the supralittoral and upper mesolittoral zones of protected and exposed sandy 


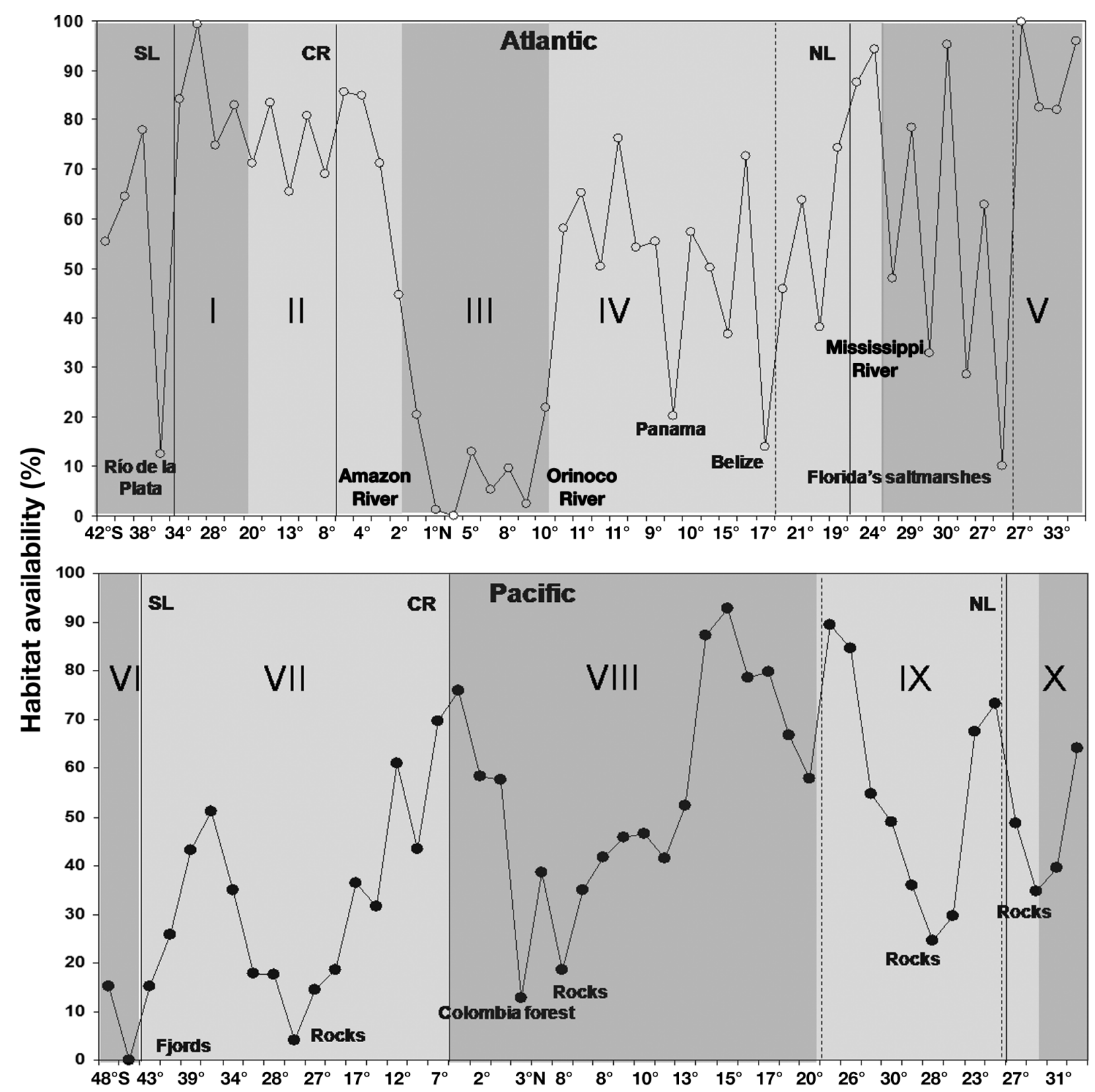

Fig. 3. Available sandy beach habitat (dots) within successive $400 \mathrm{~km}$ bins (dots, tic marks) across the range of Excirolana braziliensis and beyond; latitudes added for orientation. Repeated latitudes are due to variations in longitude. A value of 100 (zero) means that the entire (none of the) shoreline in a bin consisted of sandy beach. Solid vertical lines: published southern (SL) and northern (NL) range limits, and central range (CR). Dashed vertical lines: Gulf of Mexico limits in the Atlantic Ocean and Gulf of California limits in the Pacific Ocean. Dark and light grey zones: biogeographic provinces after Spalding et al. (2007): I: Warm Temperate SW Atlantic; II: Tropical SW Atlantic; III: North Brazil Shelf; IV: Tropical NW Atlantic; V: Warm Temperate NW Atlantic; VI: Magellanic; VII: Warm Temperate SE Pacific; VIII: Tropical Pacific; IX: Warm Temperate NE Pacific; X: Cold Temperate NE Pacific

beaches. It occurred in 4 of the 5 grain-size classes of the Wentworth (1922) grade scale, from very fine $(0.14 \mathrm{~mm})$ to coarse $(0.91 \mathrm{~mm})$ sand. Different patterns were found in the Atlantic and Pacific oceans (Table 1). In the Pacific Ocean, the species mainly occurred in beaches with fine sand $(67 \%$; Table 1$)$. The highest occurrence of $E$. braziliensis in the
Atlantic Ocean was found on beaches with medium grain size $(40 \%)$, followed by fine- and coarse-sand beaches. All of the grain sizes of beaches in which E. braziliensis was present were well represented with the species' widespread distribution among Atlantic and Pacific beaches (see Fig. S2 in the Supplement). 
Table 1. Relative frequency of sand classes of beaches where Excirolana braziliensis was present. See 'Materials and methods: Grain size' for size-class ranges

\begin{tabular}{|lcc|}
\hline Grain size & \multicolumn{2}{c|}{ Relative frequency (\%) } \\
& Atlantic Ocean & Pacific Ocean \\
\hline Very fine & 0 & 1.5 \\
Fine & 32.2 & 67.0 \\
Medium & 40.2 & 30.0 \\
Coarse & 27.6 & 1.5 \\
\hline
\end{tabular}

In the Atlantic Ocean, the CEP that joined the highest abundances at each grain size (i.e. optimal environmental conditions) was fitted with a negative linear function (abundance $=451.3-425.4 \times$ grain size; $\mathrm{R}^{2}=0.86, \mathrm{p}<0.01$ ). This relationship indicated that isopod abundance was highest for fine grains close to $0.20 \mathrm{~mm}$ in size and lowest for coarse sediments; in the latter, the differences between optimal and suboptimal conditions were reduced (Fig. 4a). In

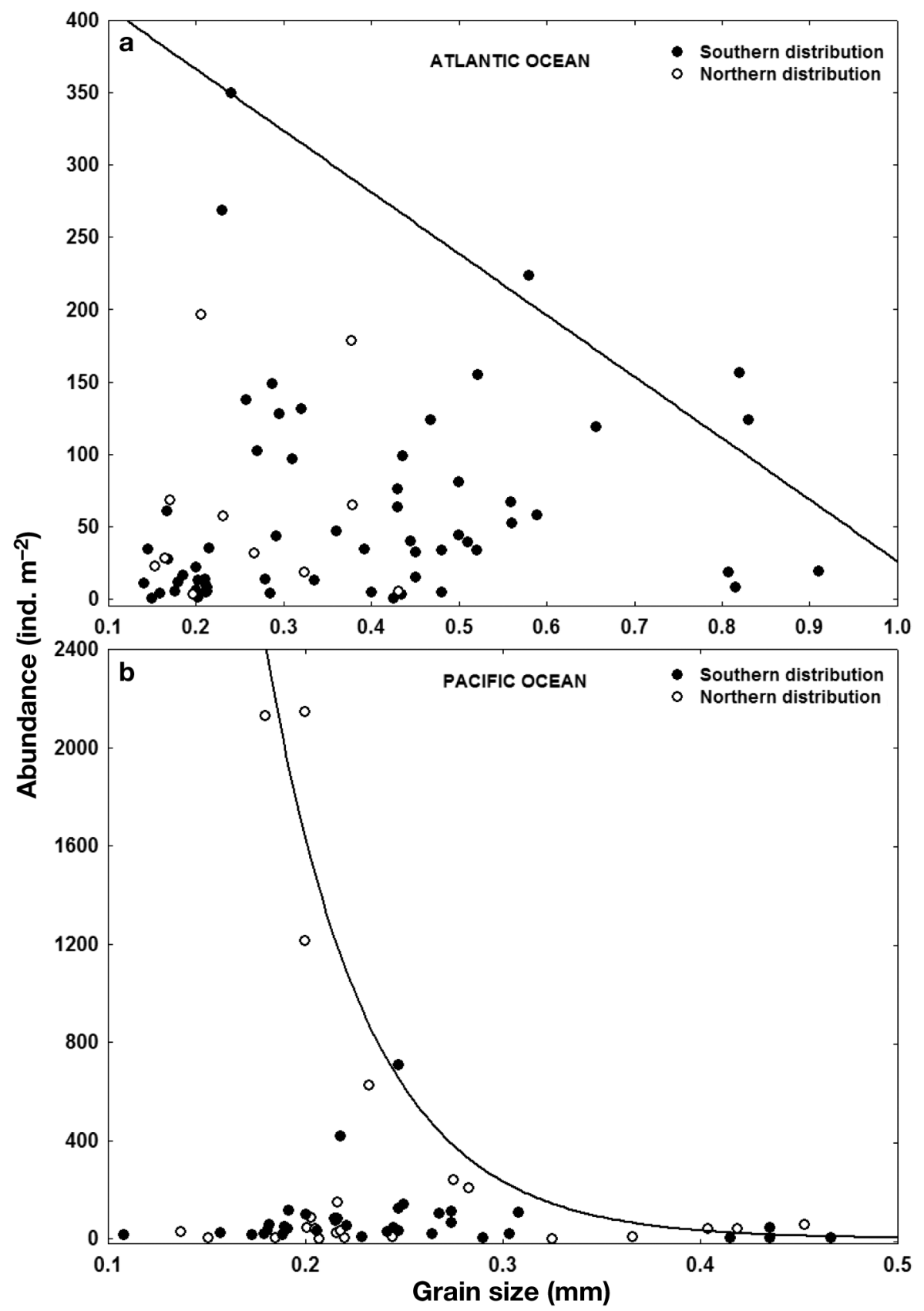

Fig. 4. Abundance of Excirolana braziliensis versus sand grain size, discriminated by centre range latitude (southern and northern distributions) in the (a) Atlantic and (b) Pacific oceans. Constraint envelope patterns for the Atlantic and Pacific oceans were fitted, respectively, by a linear and exponential function. Note different $x$ - and $y$-axis scales 
the Pacific Ocean, the CEP fit a decreasing exponential function (abundance $=79152.5 \times \exp [-19.4 \times$ grain size], $\mathrm{R}^{2}=0.87, \mathrm{p}<0.01$ ), with the highest densities found in fine sediments between 0.18 and $0.24 \mathrm{~mm}$ (Fig. 4b). Large differences between optimal and suboptimal conditions were found at this range size, whereas small differences were found in sediments of very fine and medium grain sizes.

\section{DISCUSSION}

Abundance patterns of Excirolana braziliensis across its whole geographic range on Atlantic and Pacific sandy beaches of the Americas provided partial support for the $\mathrm{ACH}$. In the Pacific Ocean, the highest abundances were observed at the range centre, but the opposite pattern was found in the Atlantic Ocean. These contrasting patterns might be explained by the different geological histories that determine the very dissimilar configuration of Atlantic and Pacific coastlines of the Americas (Kellogg \& Mohriak 2001, Mann et al. 2007), which in turn defines marked betweenocean differences in habitat availability. Indeed, abundance in the Atlantic closely followed trends in habitat availability and suitability and thereby deviated from the pattern predicted by the $\mathrm{ACH}$. However, habitat suitability in the Pacific peaked at intermediate locations of the species' range, and the $\mathrm{ACH}$ holds. Therefore, local conditions of habitat quality and morphodynamics significantly contribute to the geographic pattern. In the Atlantic Ocean, the highest abundance and predicted habitat suitability were located in 2 zones with high primary production due to coastal upwelling in the summer (see Fig. 1): (1) between 22 and $24^{\circ} \mathrm{S}$ (Rio de Janeiro; Paes \& Moraes $2007)$; and (2) in the Campeche Bank $\left(20^{\circ} \mathrm{N}\right.$, Gulf of Mexico; Zavala-Hidalgo et al. 2006). Both zones also have high water temperature $\left(24.71\right.$ and $26.44^{\circ} \mathrm{C}$, respectively). In the Pacific Ocean, the highest isopod abundances also occurred in 2 areas with high primary production and upwelling towards the centre of the range (Fig. 2b): Peru (Llanillo et al. 2012) and Panama (D'Croz \& O'Dea 2007), which also have high sea surface temperatures $\left(20.46\right.$ and $27.77^{\circ} \mathrm{C}$, respectively). Considering that similar suitability conditions can be found from the Gulf of Tehuantepec, Papagayo and Nicoya in Pacific Central America (Gocke et al. 2001, López-Calderón et al. 2006, Tapia-Garcia et al. 2007), these zones could also hold high abundances of this species.

The predicted occurrence of E. braziliensis was consistent with literature reports, except for the Car- ibbean islands, where Maxent seemed not to include them in the analysis. The highest probabilities of occurrence concurred with areas of high abundance. Overestimated areas (e.g. Atlantic coast of the USA) could be interpreted as potential areas that are not occupied by the species due to dispersal limitations (Guisan \& Zimmermann 2000, Valle et al. 2014). Refinement models for intertidal species could be obtained including habitat availability and variations in local habitat (e.g. morphodynamics in sandy beaches or protected or exposed habitats in rocky shores).

Sandy beaches are physically (tidal and/or wave) dominated systems where swash conditions play a central role in determining species richness and abundance (Defeo \& McLachlan 2005). The hard swash (waves break directly on the beach surface) excludes many intertidal species from reflective beaches, which are characterized by a low number of species, particularly in the supralittoral zone (McLachlan et al. 1995). The highest abundances of E. braziliensis occurred in beaches with fine sediments $(<0.25 \mathrm{~mm})$ and different tidal regimes: macrotidal (Panama), mesotidal (Peru) and microtidal (Rio de Janeiro, Brazil). However, southwards from Rio de Janeiro, high isopod densities were found at intermediate and reflective beaches (i.e. beaches with minimal waveenergy dissipation) with coarse sediments (Defeo et al. 1997, this study) and low local net primary production (Lercari et al. 2010). Therefore, other mechanisms are likely contributing to the geographic trends in $E$. braziliensis abundance. One possible influence is the lack of a 'safety zone' in microtidal dissipative beaches. These beaches lie very close to the South Atlantic storm belt (Vera et al. 2001) and are thus fully exposed to storm surges (Guimaraes et al. 2014), barometric tides and wind-driven surf (Parise et al. 2009, Calliari et al. 2010, Ortega et al. 2013). This exposure makes the supralitoral fringe an unpredictable and harsh environment, which precludes the existence of $E$. braziliensis populations (Defeo \& Martínez 2003). This detrimental environmental effect in beaches with fine sand might be magnified by competition with $E_{X}$ cirolana armata, which is a better swimmer than $E$. braziliensis and shows high substrate specificity for fine-grain sand (Defeo et al. 1997, Yannicelli et al. 2002).

Range limits in both oceans were congruent with biogeographic province boundaries (vanishing at definite points in space) due to the combined effects of habitat availability, surface currents and physiological constraints defined by temperature. The low abundance of the species at the central part of its range in the Atlantic Ocean might also reflect such 
effects. In the Gulf of Mexico, with northward currents (Expósito-Díaz et al. 2009) up to Mexico and high habitat availability (Fig. 3), the alongshore currents convergence zone located in Big Shell beach on Padre Island, Texas, USA (McGowen et al. 1977) sets the northern limit of the species (Fig. 1) (Tropical NW Atlantic province limit). Shelton \& Robertson (1981) indicated that cirolanid isopods were replaced by haustoriid amphipods in the Warm Temperate NW Atlantic province and above. In the Atlantic centre range, the sediment discharge of the Amazon and Orinoco Rivers (North Brazil Shelf province; Spalding et al. 2007) largely eliminates sandy beaches and forms the longest muddy coast in the world (Warne et al. 2002, Anthony et al. 2010). Between 2 and $22^{\circ} \mathrm{S}$, low abundances of $E$. braziliensis might be due to low primary production (North Brazil current) and the scarcity of dissipative beaches (Soares 2003). The southern edge of the range lies where the Río de la Plata estuary joins the marshes of Samborombon Bay, which constitute a physical barrier to dispersal. Moreover, the Uruguayan shelf is characterized by the strong influence of the diluted waters of the Río de la Plata and the convergence of shelf water masses advected by the Brazil and Malvinas Currents (Lima et al. 1996, Ortega \& Martínez 2007), constituting a 2-way flow-mediated range boundary (Gaylord \& Gaines 2000) for E. braziliensis.

In the Pacific Ocean, sandy beaches are well represented northwards from Cabo San Lucas up to $30^{\circ} \mathrm{N}$ (see Fig. 1). Considering that the cold temperate water of the California Current occurs north of Punta Eugenia ( $28^{\circ}$ N, Fig. 1) (Durazo et al. 2010), the zone between this point and Cabo San Lucas likely represents the northern limit of E. braziliensis in the Pacific Ocean. This current constitutes a 1-way (alongshore) flow-mediated boundary (Gaylord \& Gaines 2000). Moreover, Hayden \& Dolan (1976) reported the beginning of a transition zone of fauna at $30^{\circ} \mathrm{N}$ by analysing geographic ranges of 968 marine species. The following 3 concurrent effects might explain the southern limit of the species in Chiloe Island, Chile (Warm Temperate SE Pacific province limit): (1) a diverging 2-way boundary limiting dispersal (Gaylord \& Gaines 2000) between the Peru-Chile Coastal Current and the Cabo de Hornos Current (Fig. 1); (2) a lack of habitat availability, with a decline in sandy beaches to $0 \%$ due to Golfo de Corcovados and fjords (Fig. 2b); and (3) physiological stress, with the coldest mean annual temperature within the species' distribution in both oceans being registered at this location (mean $\pm \mathrm{SD}=12.15 \pm$ $\left.1.75^{\circ} \mathrm{C}\right)$.
An alternative interpretation of the discontinuous distribution in the Atlantic is the existence of cryptic species. Recent findings in Chile (Varela 2008), Panama (Spooner \& Lessios 2009) and Uruguay (Tourinho et al. 2016) suggest that E. braziliensis might be a complex of species. Furthermore, Varela (2008) showed that the congeneric E. hirsuticauda in Chile is also in the process of incipient speciation. These findings highlight the need for phylogeographic studies of the Genus Excirolana in the Americas (8 species). The direct development mode of the genus might significantly reduce gene flow among populations (particularly distant ones), promoting speciation even with low ecological divergence. If $E$. braziliensis actually represents multiple species, the biogeographical considerations presented above are equally valid at this aggregated level. However, the relationship between trends in abundances and geographic limits, with species turnover and interactions, can only be elucidated once the taxonomy of the genus is fully resolved.

In summary, abundance patterns of E. braziliensis showed opposite trends between oceans. Deviations or congruence with $\mathrm{ACH}$ expectations might be accounted for by the trends in the mechanisms that support the $\mathrm{ACH}$, e.g. habitat suitability, habitat availability and local beach morphodynamics. Both local and global trends in abundance were identified as interrelated phenomena, with main drivers operating at each scale but with a mutual influence that could not be determined from local or regional analyses. Our findings suggest that the abundance patterns of E. braziliensis appear to be more related to an environmental niche centre than to a geographic range centre. The highest abundances, which were registered in upwelling areas, high water temperatures and in dissipative beaches (fine grains, flat slopes and high local primary production), indicate the combined effects of regional and local conditions over geographic location. These findings are in agreement with a recent continental-scale analysis of aggregate patterns of macrofaunal diversity for sandy beaches in both South American ocean coasts (Defeo et al. 2017). Therefore, our results reinforce the importance of conducting a systematic analysis of main theoretical predictions and associated auxiliary hypotheses as a mandatory step for the construction of a robust biogeographic theory.

Acknowledgements. This paper is part of the $\mathrm{PhD}$ thesis of G.M., who especially thanks Lorena Frachia, and Julia and Emilia Martínez. Financial support from CSIC, ANII and PEDECIBA (Uruguay) is acknowledged. Manuscript editing was done by Nature Publishing Group (NPG) Language Editing Service. 


\section{LITERATURE CITED}

Anthony EJ, Gardel A, Gratiot N, Proisy C, Allison MA, Dolique F, Fromard F (2010) The Amazon-influenced muddy coast of South America: a review of mudbank-shoreline interactions. Earth Sci Rev 103:99-121

Baldanzi S, McQuaid CD, Cannicci S, Porri F (2013) Environmental domains and range-limiting mechanisms: testing the abundant centre hypothesis using southern African sandhoppers. PLOS ONE 8:e54598

Barboza FR, Defeo O (2015) Global diversity patterns in sandy beach macrofauna: a biogeographic analysis. Sci Rep 5:14515

Betz M, de Mathieu G, Gamba L (1982) Evolución de un derrame artificial de petróleo sobre un playa arenosa y sus efectos sobre E. braziliensis (Isopoda) (Mar CaribeVenezuela). Simp Latinoam Oceanog Biol 7:689-706

Brown JH (1984) On the relationship between distribution and abundance of species. Am Nat 124:255-279

Caddy JF, Defeo O (2003) Enhancing or restoring the productivity of natural populations of shellfish and other marine invertebrate resources. FAO Fisheries Technical Paper No. 448, FAO, Rome

Calliari LJ, Guedes RMC, Pereira PS, Lélis RF, Antiqueira JA, Fuigueredo SA (2010) Perigos e riscos associados a processos costeiros no litoral do Brasil (RS): una sintese. Braz J Aquat Sci Tech 14:51-63

* D'Croz L, O'Dea A (2007) Variability in upwelling along the Pacific shelf of Panama and implications for the distribution of nutrients and chlorophyll. Estuar Coast Shelf Sci 73:325-340

* Defeo O, Martínez G (2003) The habitat harshness hypothesis revisited: life history of the isopod Excirolana braziliensis in sandy beaches with contrasting morphodynamics. J Mar Biol Assoc UK 83:331-340

Defeo O, McLachlan A (2005) Patterns, processes and regulatory mechanisms in sandy beach macrofauna: a multiscale analysis. Mar Ecol Prog Ser 295:1-20

Defeo O, Brazeiro A, Alava A, Riestra G (1997) Is sandy beach macrofauna only physically controlled? Role of substrate and competition in isopods. Estuar Coast Shelf Sci 45:453-462

Defeo O, Barboza CAM, Barboza FR, Aeberhard WH and others (2017) Aggregate patterns of macrofaunal diversity: an interocean comparison. Glob Ecol Biogeogr 26: 823-834

Durazo R, Ramírez-Manguilar AM, Miranda LE, Soto-Mardones LA (2010) Climatología de variables hidrográficas. In: Gaxiola-Castro G, Durazo R (eds) Dinámica del ecosistema pelágico frente a Baja California, 1997-2007. Secret Medio Amb Rec Nat, Mexico DF, p 25-57

Egbert GD, Erofeeva SY (2002) Efficient inverse modeling of barotropic ocean tides. J Atmos Ocean Technol 19: 183-204

Expósito-Díaz G, Salas-de León DA, Monreal-Gómez MA, Salas-Monreal D, Vázquez-Gutiérrez F (2009) Corrientes inerciales en el sur del Golfo de México. Cienc Mar 35: 287-296

Fenberg PB, Rivadeneira MM (2011) Range limits and geographic patterns of abundance of the rocky intertidal owl limpet, Lottia gigantea. J Biogeogr 38:2286-2298

Gaylord B, Gaines SD (2000) Temperature or transport? Range limits in marine species mediated solely by flow. Am Nat 155:769-789

* Gocke K, Cortés J, Murillo MM (2001) The annual cycle of primary productivity in a tropical estuary: the inner regions of the Golfo de Nicoya, Costa Rica. Rev Biol Trop 49(Suppl 2):289-306

Guimaraes PV, Farina L, Toldo E (2014) Analysis of extreme events in the southern coast of Brasil. Nat Hazards Earth Syst Sci 2:4363-4391

* Guisan A, Zimmermann NE (2000) Predictive habitat distribution models in ecology. Ecol Modell 135:147-186

* Hayden BP, Dolan R (1976) Coastal marine fauna and marine climates of the Americas. J Biogeogr 3:71-81

*Hermosilla C, Rocha F, Valavanis VD (2011) Assessing Octopus vulgaris distribution using presence-only model methods. Hydrobiologia 670:35-47

Jaramillo E, Dugan JE, Hubbard DM, Melnick D and others (2012) Ecological implications of extreme events: footprints of the 2010 earthquake along the Chilean coast. PLOS ONE 7:e35348

Kaschner K, Ready JS, Agbayani E, Rius J and others (2008) AquaMaps environmental dataset: half-degree cells authority file (HCAF). www.aquamaps.org/main/envt_ data.php

Kellogg JN, Mohriak WU (2001) The tectonic and geological environment of coastal South America. In: Seeliger U, Kjerfve B (eds) Coastal marine ecosystems of Latin America. Springer-Verlag, Berlin Heidelberg, p 1-16

Lee MR, Riberos M (2011) Latitudinal trends in the species richness of free-living marine nematode assemblages from exposed sandy beaches along the coast of Chile (18-42 $\left.{ }^{\circ}\right)$. Mar Ecol 33:317-325

* Lercari D, Bergamino L, Defeo O (2010) Trophic models in sandy beaches with contrasting morphodynamics: comparing ecosystem structure and biomass flow. Ecol Modell 221:2751-2759

* Lima ID, Garcia CAE, Möller O (1996) Ocean surface processes on the southern Brazilian shelf: characterization and seasonal variability. Cont Shelf Res 16:1307-1317

* Llanillo PJ, Pelegrí JL, Duarte CM, Emelianov M, Gasser M, Gourrion J, Rodríguez-Santana A (2012) Meridional and zonal changes in water properties along the continental slope off central and northern Chile. Cienc Mar 38: 307-332

* López-Calderón J, Manzo-Monroy H, Santamaría-del-Ángel E, Castro R, González-Silvera A, Millán-Núñez R (2006) Variabilidad de mesoescala del Pacífico tropical mexicano mediante datos de los sensores TOPEX y SeaWiFS. Cienc Mar 32:539-549

Mann P, Rogers RD, Gahagan L (2007) Overview of plate tectonic history and its unresolved tectonic problems. In: Bundschuh J, Alvarado G (eds) Geology, resources, and hazards, Vol 1. Taylor and Francis, London, p 201-232

*Martínez G, Defeo O (2006) Reproductive biology of the isopod Excirolana braziliensis at the southern edge of its geographical range. Helgol Mar Res 60:273-280

*Martínez-Meyer E, Díaz-Porras D, Townsend Peterson A, Yañez-Arenas C (2013) Ecological niche structure and range wide abundance patterns of species. Biol Lett 9: 20120637

McGill B, Collins C (2003) A unified theory for macroecology based on spatial patterns of abundance. Evol Ecol Res 5:469-492

McGowen JH, Garner LE, Wilkinson BH (1977) The gulf shoreline of Texas: processes, characteristics, and factors in use. Geological Circular No. 77-3, Bureau of Economic Geology, University of Texas, Austin, TX

* McLachlan A, Jaramillo E, Defeo O, Dugan J, de Ruyck A, 
Coetzee P (1995) Adaptations of bivalves to different beach types. J Exp Mar Biol Ecol 187:147-160

Nava ML, Severeyn HJ (2010) Variación espacial del macrobentos intermareal en playas arenosas de alta energía del noroeste del Golfo de Venezuela. Ciencia 18:235-246

Ortega L, Martínez A (2007) Multiannual and seasonal variability of water masses and fronts over the Uruguayan shelf. J Coast Res 23:618-629

* Ortega L, Celentano E, Finkl C, Defeo O (2013) Effects of climate variability on the morphodynamics of Uruguayan sandy beaches. J Coast Res 29:747-755

Paes ET, Moraes LES (2007) A new hypothesis on the influence of the El Niño/La Niña upon the biological productivity, ecology and fisheries of the Southern Brazilian Bight. Pan-Am J Aquat Sci 2:94-102

Parise CK, Calliari LJ, Krusche N (2009) Extreme storm surges in the south of Brazil: atmospheric condition and shore erosion. Braz J Oceanogr 57:175-188

* Phillips SJ, Anderson RP, Schapire RE (2006) Maximum entropy modelling of species geographic distributions. Ecol Modell 190:231-259

Phillips SJ, Anderson RP, Dudík M, Schapire RE, Blair ME (2017) Opening the black box: an open-source release of Maxent. Ecography 40:887-893

R Development Core Team (2007) R: a language and environment for statistical computing. R Foundation for Statistical Computing, Vienna

Rangel TF, Alexandre J, Diniz-Filho F, Bini LM (2006) SAM: a comprehensive application for spatial analysis in macroecology. Ecography 33:46-50

Rivadeneira MM, Hernández P, Baeza JA, Boltaña S and others (2010) Testing the abundant-centre hypothesis using intertidal porcelain crabs along the Chilean coast: linking abundance and life-history variation. J Biogeogr 37:486-498

Sagarin RD, Gaines SD (2002a) The 'abundance centre' distribution: to what extent is it a biogeographical rule? Ecol Lett 5:137-147

Sagarin RD, Gaines SD (2002b) Geographical abundance distributions of coastal invertebrates: using one-dimensional ranges to test biogeographic hypotheses. J Biogeogr 29: 985-997

Sagarin RD, Gaines SD, Gaylord B (2006) Moving beyond assumptions to understand abundance distributions across the ranges of species. Trends Ecol Evol 21:524-530

Samis KE, Eckert CG (2007) Testing the abundant center model using range-wide demographic surveys of two coastal dune plants. Ecology 88:1747-1758

Shelton CR, Robertson PB (1981) Community structure of intertidal macrofauna on two surf-exposed Texas sandy beaches. Bull Mar Sci 31:833-842

Soares AG (2003) Sandy beach morphodynamics and macrobenthic communities in temperate subtropical and tropical regions in a macroecological approach. $\mathrm{PhD}$ thesis, University of Port Elizabeth

Spalding MD, Fox HE, Allen GR, Davidson N and others (2007) Marine ecoregions of the world: a bioregionaliza-

Editorial responsibility: Simonetta Fraschetti, Salento, Italy tion of coastal and shelf areas. J Biosci 57:573-583

Spooner R, Lessios HA (2009) Mitochondrial phylogeography of the intertidal isopod Excirolana braziliensis on the two sides of the Isthmus of Panama. Smithson Contrib Mar Sci 38:219-228

Tam JC, Scrosati RA (2011) Mussel and dogwhelk distribution along the north-west Atlantic coast: testing predictions derived from the abundant-centre model. J Biogeogr 38:1536-1545

Tapia-Garcia M, Garcia-Abad MC, Carranza-Edwards A, Vazquez F (2007) Environmental characterization of the continental shelf of the Gulf of Tehuantepec, Mexico. Geofis Int 46:249-260

* Tourinho JL, Márquez A, Celentano E, Defeo O (2016) A new evolutionary unit in the Excirolana braziliensis species complex. Braz J Oceanogr 64:197-202

* Tuya F, Wernberg T, Thomsen MS (2008) Testing the 'abundant centre' hypothesis on endemic reef fishes in southwestern Australia. Mar Ecol Prog Ser 372:225-230

Valle M, Chust G, del Campo A, Wisz MS, Olsen SM, Garmendia JM, Borja A (2014) Projecting future distribution of the seagrass Zostera noltii under global warming and sea level rise. Biol Conserv 170:74-85

Varela AI (2008) Filogeografía, estructura genética e historia demográfica de Excirolana hirsuticauda y E. brazilíensis (Crustacea: Peracarida: Isopoda) en la costa de Chile. MSc thesis, Universidad Católica del Norte, Coquimbo

Veloso VG, Neves G, Almeida Cappera L (2011) Sensitivity of a cirolanid isopod to human pressure. Ecol Indic 11: 782-788

Vera CS, Vigliarolo PQ, Berbery EH (2001) Cold season synoptic-scale waves over subtropical South America. Mon Weather Rev 130:684-699

*Vieira JV, Borzone CA, Lorenzi L, Grecco de Carvalho F (2012) Human impact on the benthic macrofauna of two beach environments with different morphodynamic characteristics in southern Brazil. Braz J Oceanogr 60: 135-148

Warne AG, Meade RH, White WA, Guevara EH and others (2002) Regional controls on geomorphology, hydrology, and ecosystem integrity in the Orinoco Delta, Venezuela. Geomorphology 44:273-307

Weinberg JR, Starczak VR (1988) Morphological differences and low dispersal between local populations of the tropical beach isopod, Excirolana braziliensis. Bull Mar Sci 42:296-309

*Wentworth CH (1922) A scale of grade and class terms for clastic sediments. J Geol 30:377-392

* Yannicelli B, Palacios R, Giménez L (2002) Swimming ability and burrowing time of two cirolanid isopods from different levels of exposed sandy beaches. J Exp Mar Biol Ecol 273:73-88

Zavala-Hidalgo J, Gallegos-García A, Martínez-López B, Morey SL, O'Brien JJ (2006) Seasonal upwelling on the western and southern shelves of the Gulf of Mexico. Ocean Dyn 56:333-338

Submitted: December 15, 2016; Accepted: September 10, 2017 Proofs received from author(s): October 31, 2017 